\title{
Immune response induced in mice by oral immunization with cowpea severe mosaic virus
}

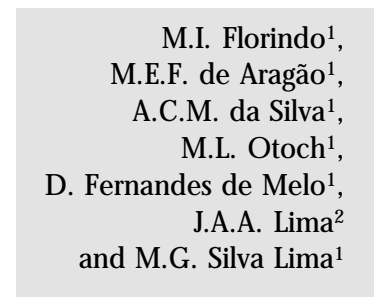

\author{
${ }^{1}$ Departamento de Bioquímica e Biologia Molecular, and \\ ${ }^{2}$ Laboratório de Virologia Vegetal, U niversidade Federal do Ceará, \\ Fortaleza, CE, Brasil
}

\section{Correspondence \\ M.G. Silva Lima \\ Departamento de Bioquímica e \\ Biologia Molecular, UFC \\ Caixa Postal 6029 \\ 60455-900 Fortaleza, CE \\ Brasil \\ Fax: + 55-85-288-9789 \\ E-mail: maguia@ufc.br}

Research supported in part by CN Pq.

Received June 8, 2001

Accepted April 29, 2002

\section{Abstract}

There is increasing interest in the immune response induced by plant viruses since these could be used as antigen-expressing systems in vaccination procedures. Cowpea severe mosaic virus (CPSMV), as a purified preparation (300 g of leaves, 2 weeks post-inoculation), or crude extract from cowpea (Vigna unguiculata) leaves infected with CPSMV both administered by gavage to Swiss mice induced a humoral immune response. Groups of 10 Swiss mice (2-month-old females) were immunized orally with 10 daily doses of either $50 \mu \mathrm{g}$ viral capsid protein (boosters of $50 \mu \mathrm{g}$ at days 21 and 35 after immunization) or $0.6 \mathrm{mg}$ protein of the crude extract (boosters of 0.6 $\mathrm{mg}$ at days 21 and 35 after immunization). Anti-CPSMV antibodies were quantified by ELISA in pooled sera diluted at least 1:400 at days 7, 14, 21, 28, 35 and 42 after the 10th dose. IgG and IgA against CPSMV were produced systemically, but IgE was not detected. No synthesis of specific antibodies against the proteins of leaf extracts from $V$. unguiculata, infected or not with CPSMV, was detected. The use of CPSMV, a plant-infecting virus that apparently does not induce a pathogenic response in animals, induced a humoral and persistent (at least 6 months) immune response through the administration of low antigen doses by gavage. These results raise the possibility of using CPSMV either as a vector for the production of vaccines against animal pathogens or in quick and easy methods to produce specific antisera for viral diagnosis.

\section{Introduction}

Plant viruses, recognized to be nonpathogenic to humans and other animals, are attracting much attention because of the increasing possibility of using them as antigen expression systems (1). Different species of viruses belonging to several families and genera (1-9) have been used for this purpose.

\section{Key words}

- Oral immunization

- Plant virus

- Plant virus immunogenicity

- Cowpea severe mosaic virus 
same family and genus (12). The capsid of CPSMV is made of proteins in at least four conformational states (13) and, as in other Comovirus species, is reported to contain glycosylated proteins $(14,15)$. Recently, however, the glycosylation of CPMV coat proteins has been reinvestigated and denied (16). We have shown that a systemic immune response is induced in mice orally fed purified CPSMV or a leaf extract from CPSMVinfected cowpea (Vigna unguiculata (L.) Walp.) subsp. unguiculata (17). Of particular interest was the immune response induced by CPSMV via oral immunization. Oral immunization is known to stimulate mucosal and systemic antibodies that play an important role in the defense against pathogens (18). The oral immunization route tends to be related to systemic tolerance (19), especially against the $T$ cell-mediated immune reactions associated with delayed type hypersensitive inflammatory reactions (20). The present study demonstrated a systemic immune response in Swiss mice that were immunized orally with either purified CPSMV or leaf extract from CPSMV-infected cowpea plants, and the synthesis of specific IgG1 and IgA.

\section{Material and Methods}

\section{Virus purification}

CPSMV was purified (21) from leaf tissue of cowpea plants 21 days after virus inoculation. Leaf tissue was ground in a blender with $100 \mathrm{mM}$ potassium phosphate buffer, $\mathrm{pH} 7.5$, at a 1:2 ratio (w/v), $8.0 \%$ of $n$-butanol was added to the resulting extract and the mixture was stirred overnight. The mixture was then clarified by centrifugation at $10,000 \mathrm{~g}$ for $10 \mathrm{~min}$ and virus particles were precipitated by adding $6 \%$ polyethylene glycol 6000 (PEG) and 4\% $\mathrm{NaCl}$. The mixture was then stirred for $1 \mathrm{~h}$ at $4^{\circ} \mathrm{C}$, followed by centrifugation at $10,000 \mathrm{~g}$ for 10 min. The pellet containing virus particles was suspended in $0.1 \mathrm{M}$ phosphate buffer, $\mathrm{pH} 7.5$, and clarified by further centrifugation. Additional purification was obtained by three cycles of differential centrifugation, using PEG as described above. Finally, the virus suspension was submitted to ultracentrifugation at $120,000 \mathrm{~g}$ for $2 \mathrm{~h}$ and the protein content was estimated (22).

\section{Crude leaf extract preparation}

The crude leaf extracts were obtained from both healthy cowpea and cowpea infected with CPSMV. The leaves were homogenized in a blender with a $0.1 \mathrm{M} \mathrm{NaCl}$ solution at a ratio of $1: 1(\mathrm{w} / \mathrm{v})$. The extracts thus obtained were filtered through a double layer of cheesecloth, the protein content was determined (22), and the extracts were stored at $-20^{\circ} \mathrm{C}$ in aliquots of $0.5 \mathrm{ml}$.

\section{Oral immunization}

Three groups of 10 two-month-old female Swiss mice (provided by the Central Animal House of Universidade Federal do Ceará) received by gavage daily doses of either purified CPSMV preparation containing $50 \mu \mathrm{g}$ of viral capsid protein, or crude leaf extract from CPSMV-infected plants containing $0.6 \mathrm{mg}$ protein, or crude leaf extract of uninfected plants ( $0.6 \mathrm{mg}$ protein) as control. These antigen doses were given to the mice by gavage in $0.2 \mathrm{ml}$ over 10 consecutive days. Boosters ( $50 \mu \mathrm{g}$ viral capside protein or $0.6 \mathrm{mg}$ protein crude extracts) were also given by gavage 21 and 35 days after starting oral immunization. The mice were bled from the retro-orbital plexus to obtain antiserum at days 7, 14, 21, 28, 35, 42 and 50 after starting immunization.

\section{Double immunodiffusion (Ouchterlony)}

All antisera obtained from immunized mice were tested serologically by double diffusion on agar medium with $0.75 \%$ noble 
agar, $0.9 \% \mathrm{NaCl}$ and $0.05 \% \mathrm{NaN}_{3}$. The antiserum reactivity was tested against purified CPSMV and crude leaf extracts from CPSMV-infected and -uninfected plants.

\section{Enzyme-linked immunosorbent assay}

The immune response induced by CPSMV was evaluated by enzyme-linked immunosorbent assay (ELISA). Purified CPSMV (6 $\mu \mathrm{g}$ protein), and crude leaf extracts of CPSMV-infected and -uninfected plants diluted in $50 \mathrm{mM}$ sodium carbonate buffer, $\mathrm{pH}$ 9.6, at a final volume of $100 \mu \mathrm{l}$ were used to coat the 96-well plates. The plates were incubated at $4^{\circ} \mathrm{C}$ overnight after which they were blocked with $5 \%$ nonfat milk in $10 \mathrm{mM}$ potassium phosphate buffer, $\mathrm{pH} 7.2$, with $0.9 \% \mathrm{NaCl}$ (PBS) for $2 \mathrm{~h}$ at room temperature, washed once, and $100 \mu \mathrm{l}$ of the appropriate sera diluted in PBS $(1: 10$ to $1: 1280)$ was added and reincubated overnight at $4^{\circ} \mathrm{C}$. The plates were washed five times with $0.05 \%$ PBS-Tween 20 and treated with peroxidase-conjugated rabbit antimouse IgG $(100 \mu \mathrm{l} /$ well, 1:1000 final dilution) for $2 \mathrm{~h}$ at room temperature. The plates were subsequently washed five times with PBS-Tween 20. The reaction was developed by the addition of orthophenylenediamine followed by incubation for $20 \mathrm{~min}$ at $37^{\circ} \mathrm{C}$ and then stopped by the addition of $20 \mu \mathrm{l}$ of $2.5 \mathrm{~N} \mathrm{H}_{2} \mathrm{SO}_{4}$ and the intensity of the resulting color was read at $492 \mathrm{~nm}$. The results are reported as the mean values of the absorbance obtained for the sera at different dilutions.

\section{Quantitative immunoprecipitation}

Immunoprecipitation was carried out by incubating at $4^{\circ} \mathrm{C}$ overnight $50 \mu \mathrm{l}$ of $100 \mathrm{mM}$ potassium phosphate buffer, $\mathrm{pH} 7.5$, containing $350 \mu \mathrm{g}$ of viral capsid proteins plus $50 \mu \mathrm{l}$ of the polyclonal antiserum (obtained 15 days after the booster) from mice orally fed the crude leaf extract from infected plants.
The resulting pellet was washed with distilled water and suspended in $20 \mathrm{mM}$ Tris$\mathrm{HCl}$ buffer, $\mathrm{pH} 7.5$, containing $1 \%$ Triton $\mathrm{X}-$ $100(\mathrm{v} / \mathrm{v})$ and $500 \mathrm{mM} \mathrm{NaCl}$ and centrifuged for $10 \mathrm{~min}$ at $9,800 \mathrm{~g}$. The new pellet was submitted to the same treatment. The resulting pellet was washed three times with 10 $\mathrm{mM}$ phosphate buffer, $\mathrm{pH} 7.2$, containing $0.1 \%$ SDS in order to eliminate the Triton. The resuspended pellet was submitted to SDS-PAGE under denaturing conditions according to Laemmli (23). Electrophoresis was performed using stacking and main gels with bis-polyacrylamide at concentrations of 4 and 12\%, respectively. Following SDSPAGE, transfer to a nitrocellulose membrane was carried out using a Hoefer transfer electrophoresis system (24). The antibodies that reacted to the corresponding antigens on membranes were detected with anti-mouseIgG-peroxidase conjugate or anti-mouse-IgAphosphatase conjugate and visualized by peroxidase and phosphatase activity, respectively.

\section{Western blotting analysis}

Samples of $10 \mu \mathrm{l}$ purified CPSMV, $10 \mu \mathrm{l}$ leaf crude extract from uninfected and from infected plants were submitted to SDS-PAGE (23) and then transferred to a nitrocellulose membrane (24) as described above. The nitrocellulose membrane was probed with serum from mice immunized orally with crude leaf extract from CPSMV-infected plants. The blots were visualized with peroxidaseconjugated rabbit antiserum to mouse $\mathrm{IgG}$, and color development reagents diaminobenzidine tetrahydrochloride/ $\mathrm{NiCl}_{2} / \mathrm{H}_{2} \mathrm{O}_{2}$.

\section{Passive cutaneous anaphylaxis for $\lg \mathrm{G} 1$ and $\lg E$}

CPSMV-specific IgG1 antibodies were detected in pooled mouse sera using a 2-h latent period for skin sensitization (25). Intradermal injections of the antisera or their 
dilutions were made into the dorsal skin of shaved normal mice. Volumes of $50 \mu \mathrm{l}$ were injected with a $100-\mu l$ syringe and a 26gauge hypodermic needle. The passive cutaneous anaphylaxis (PCA) reactions were challenged by intravenous (retro-orbital plexus) injections of the antigens, $250 \mu \mathrm{g}$ of viral capsid protein in $250 \mu \mathrm{l}$ of saline containing $0.5 \%$ Evans blue. After $30 \mathrm{~min}$, mice were sacrificed and the reaction was detected by the blue area formed on the inner surface of the skin.

The presence of specific IgE in pooled mouse sera was determined in rats (26) using a 18-h latent period for skin sensitization. Intradermal injections of the antisera or their dilutions were made into the shaved dorsal skin of normal rats. A $100-\mu l$ volume was injected with a 1.0-ml syringe and a 26-gauge hypodermic needle. The PCA reactions were challenged by intravenous injection (vein of the penis) of the antigens (500 $\mu \mathrm{g}$ of viral capsid protein, or $1.0 \mathrm{mg}$ of crude leaf extracts of infected or uninfected plants) in $1.0 \mathrm{ml}$ of saline containing $0.5 \%$ Evans blue. After 30 min, rats were sacrificed and the reaction was visualized on the basis of the blue area formed on the inner surface of the skin.

\section{Statistical analysis}

Differences between groups were analyzed by the Duncan test. Probability (P) values less than 0.05 were considered to be significant.

\section{Results}

Synthesis of specific CPSMV antibodies detected by double immunodiffusion and ELISA

Immunodiffusion tests carried out with the antisera of mice immunized orally with purified CPSMV or crude leaf extracts from CPSMV-infected plants contained specific antibodies against the virus. The reactivity of the antisera was detected up to 1:64 dilu- tion (Figure 1A,B). No reaction was observed when crude leaf extract from uninfected plants was used.

The results obtained by ELISA (Figure 2) confirmed the production of specific antibodies against CPSMV (Figure 1). When the antigen consisted of purified CPSMV, the titers of specific antibodies were significantly higher $(\mathrm{P} \leq 0.05)$ than those obtained when the crude leaf extract from CPSMV-infected plants was used as the antigen. The production of specific antibodies against CPSMV was monitored up to 42 days after starting immunization. Specific antibody production increased strongly 7 days after the beginning of immunization and was maintained until the 42nd day, with slight increases after the boosters at days 21 and 35 (Figure 3).

\section{Synthesis of anti-CPSMV IgG 1 detected by PCA, and specific IgG and IgA detected by immunoblotting}

The presence of anti-CPSMV IgG1 was detected by PCA in mice injected with sera at the dilutions of 1:2, 1:4 and 1:8, respectively, 14, 35 and 42 days after starting immunization with the crude leaf extract of CPSMV-infected plants. The PCA reaction was challenged with purified CPSMV. Increasingly positive reactions were observed from a primary immune response 14 days after starting immunization to a secondary response 14 days after the first booster, and a tertiary response 7 days after the second booster (Figure 4). No reaction against CPSMV was detected with mouse sera even at the dilution of 1:2, 35 days after immunization with crude leaf extract from CPSMVuninfected plants (Figure 4).

The antisera obtained from animals immunized with purified CPSMV or with crude extract from CPSMV-infected and -uninfected plants were submitted to PCA for IgE detection, and no IgE synthesis was detected in any case (data not shown).

The presence of anti-CPSMV IgG and 
A
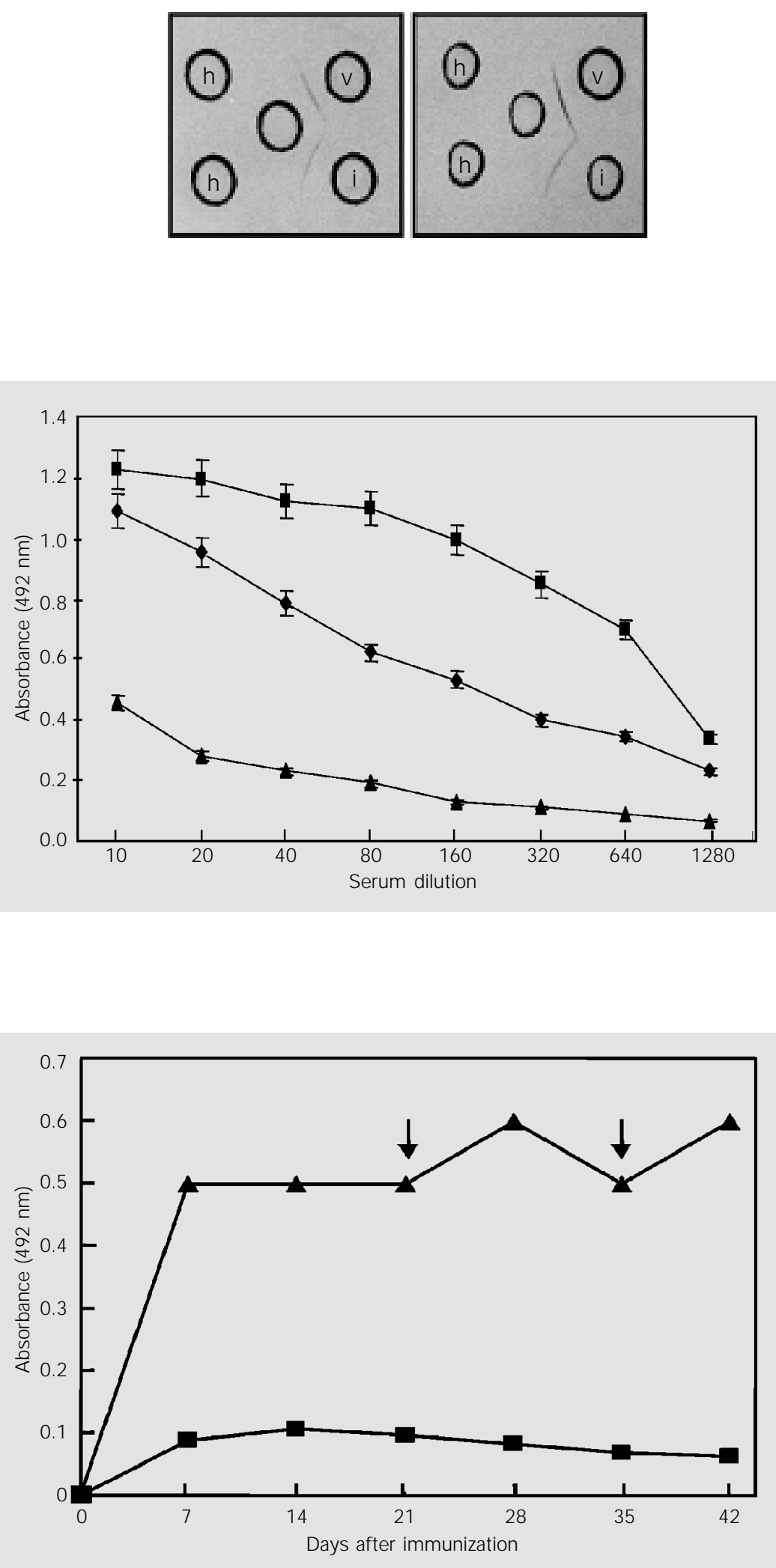

Figure 1. CPSMV-specific senum antibody response 14 days after an oral booster detected by double immunodiffusion on agar medium. The central wells contained $10 \mu \mathrm{l}$ of a 1:4 dilution of antisera: A, from Swiss mice immunized orally with purified CPSMV (10 doses of 50 $\mu \mathrm{g}$ viral capsid protein); B, from Swiss mice immunized orally with crude leaf extract from CPSMV-infected plants (10 doses of $0.6 \mathrm{mg}$ protein). The peripheral wells contained antigens: $v, 5 \mu \mathrm{g}$ of purified virus; i, crude leaf extract $(1: 2, w / v)$ from CPSMV-infected plants; $h$, crude leaf extract $(1: 2, w / v)$ from uninfected plants.

Figure 2. CPSMV-specific serum antibody response of mice immunized orally with a crude leaf extract from CPSMV-infected plants 14 days after an oral booster, detected by ELISA. Purified virus (squares); crude leaf extract from CPSMV-infected plants (lozenges); crude leaf extract from uninfected plants (triangles). The ELISA response to purified virus and leaf extract from CPSMV-infected plants was significantly higher than to leaf extract from uninfected plants $(P \leq 0.05$, Duncan test).

Figure 3. Kinetics of CPSMV-specific serum antibody production in mice immunized orally with crude leaf extract from CPSMV-infected plants measured by ELISA. A serum dilution of 1:400 from mice immunized orally (triangles) and sera from preimmune mice (squares) were used. The antigen was purified CPSMV. Arrows indicate the days of booster injections. 
IgA was shown (Figure 5) by the fact that the immunoprecipitate reacted with anti-mouse IgG antibodies (visualized by the peroxidase activity developed) as well as with antimouse IgA antibodies (visualized by the phosphatase activity developed). The exclusive synthesis of anti-CPSMV IgG was also detected in mice immunized orally with crude leaf extract from CPSMV-infected plants (Figure 6).

\section{Discussion}

The present study has shown a systemic immune response in mice immunized orally with purified CPSMV or crude leaf extract of CPSMV-infected cowpea plants in the absence of immunoadjuvants. The specific antibodies synthesized against the CPSMV coat protein were detected by immunodiffusion (Figure 1A,B), ELISA (Figures 2 and 3), PCA (Figure 4) and immunoblots (Figures 5 and 6), while specific antibodies against cowpea proteins were not detected (Figures 1 and 6). Intraperitoneal immunization of mice with recombinant alfalfa mosaic virus particles containing antigen determinants of rabies virus or HIV did not require adjuvant co-administration for an effective immune response (27). Furthermore, virus particles survived in the gastrointestinal tract of mice orally immunized with the same chimeric plant and stimulated serum IgG and IgA synthesis without the use of an adjuvant (1). These results call attention to the potential use of recombinant plant viruses as mucosal vaccines, since they do not require the use of adjuvants in oral immunization procedures. More recently, the humoral immune responses to the D2 peptide of fibronectin-binding protein B of Staphylococcus aureus expressed in CPMV were evaluated after mucosal delivery to mice. Recombinant CPMV was demonstrated to induce mucosal and serum immune responses (11). Since it is unlikely that murine epithelial cells possess receptors for CPMV, presumably the size and particulate nature of the chimeric virus particles allow them to be efficiently taken up and retained by M-cells in gut and nasal-associated lymphoid tissue which present them to the lymphoid cells in the underlying tissues. Apparently, the ability to stimulate a strong mucosal and systemic immune response after delivery of antigens to the mucosa is not an intrinsic property of plant viruses since rod-shaped potato virus $\mathrm{X}$, expressing the $\mathrm{D} 2$ peptide of fibronectin-binding protein B of $S$. aureus, generated a strong immune response after subcutaneous immunization but is poorly immunogenic after intranasal delivery. The explanation for this fact was ascribed to the icosahedral structure of CPMV that could be important in facilitating mucosal uptake and immune recognition (11). It was shown in a recent study that the conformational state of the coat protein of CPSMV, a virus closely related to CPMV (28), could exist in at least four states (13).

Internalization of the virus through the gastrointestinal tract might also be based on the structural properties of the antigen molecule. Thus, the immunogenicity of the CPSMV capsid proteins could be attributed to their "lectin-like" binding activities, which are comparable to similar activities found in bacterial pili, lectins, cholera labile toxin B subunit, and viral hemagglutinin. These are all known to bind to the glycolipids or glycoproteins of the intestinal mucosa cells, thus stimulating these cells to transport the antigen into the systemic circulation (29-33).

Another explanation is that viral coat proteins, instead of binding to the mucosa, could be trapped by cell membrane lectins such as galectins, widely distributed in the gastrointestinal tract of mammals (34), and then be internalized. Recent studies (16) have shown that the coat proteins of CPMV, closely related to CPSMV (28), are not glycosylated.

The selective immunogenic capacity of the CPSMV capsid proteins, as compared to 

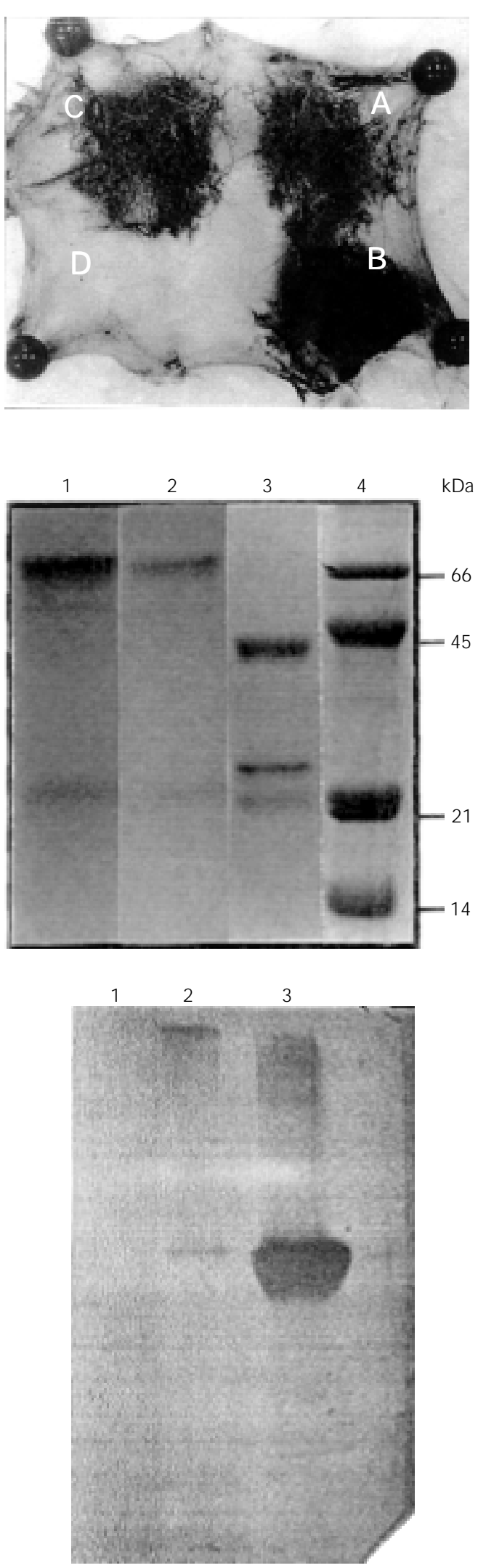

Figure 4. CPSMV-specific serum antibody (IgG1) response of mice detected by passive cutaneous anaphylaxis (PCA). A, Antisenum obtained from mice 14 days after starting oral feeding with crude leaf extract from CPSMV-infected plants, at 1:2 dilution. B, Antiserum obtained from mice 35 days ( 14 days after the 1st booster) after starting oral feeding with crude leaf extract from CPSMVinfected plants, at 1:4 dilution. C, Antiserum obtained from mice 42 days ( 7 days after the 2 nd booster) after starting oral feeding with crude leaf extract from CPSMV-infected plants, at 1:8 dilution. $\mathrm{D}$, Antiserum obtained from mice 35 days ( 14 days after the 1st booster) after starting oral feeding with crude leaf extract from uninfected plants, at 1:4 dilution. The PCA reaction was challenged by $250 \mu \mathrm{g}$ viral capsid protein in $250 \mu$ saline containing $0.5 \%$ Evans blue. The other experimental conditions are described in Material and Methods.

Figure 5. CPSMV-specific serum antibody (IgG and IgA) response of mice detected by immunoblot after immunoprecipitation of purified virus with antisenum obtained from Swiss mice immunized orally with crude leaf extract of CPSMV-infected plants. The immunoprecipitate was submitted to SDS-PAGE and transferred to a nitrocellulose membrane and the antibodies were visualized with anti-IgG1 peroxidase conjugate (lane 1 ) and anti-lgA alkaline phosphatase conjugate (lane 2). Lanes 3 and 4 correspond to purified CPSMV $(7 \mu \mathrm{g})$ and molecular weight standards, respectively, and were stained with Coomassie blue.

Figure 6. CPSMV-specific serum antibody response of mice detected by Western blotting after SDS-PAGE of sera obtained from mice immunized orally with crude leaf extract from CPSMV-infected plants. Lane 1, Crude leaf extract from uninfected plants; lane 2, crude leaf extract from infected plants, and lane 3, purified CPSMV. 
the plant proteins present in the crude leaf extract, might be attributed to the association of the coat proteins with the genetic material (RNA) of CPSMV. The RNA may play an adjuvant role. It is well known that RNA, and mainly DNA, are being used in vaccines for humans, based on plasmid vectors expressing an antigen under the control of a strong promoter (35). The adjuvant effect of DNA has been explained by the presence on the plasmid backbone of unmethylated cytosine preceding guanosine $(\mathrm{CpG}$ motif) that possesses important immunomodulatory properties. The immunomodulatory effect of RNA is not understood $(35,36)$.

Specific synthesis of IgG (Figures 2, 3, and 4) and specific synthesis of $\operatorname{IgG}$ and $\operatorname{IgA}$ (Figure 5) were demonstrated in sera of mice immunized orally with purified CPSMV or crude leaf extract of plants infected with CPSMV. Comparable results have been obtained with viral particles of CPMV (11) and alfalfa mosaic virus (1). In the present experiments, no specific IgE synthesis was observed. Indeed, the experiments carried out with recombinant viral particles also did not mention specific IgE synthesis $(1,11)$. Furthermore, previous studies using oral immunizations have reported sensitization of IgE suppressor cells (29) with concomitant suppression of serum $\operatorname{IgE}$ response due to tolerance induced by oral feeding with proteins (37).

Oral administration of CPSMV was shown to induce a durable (Figure 3 ) and preferential systemic immune response without the presence of adjuvants. This indicates that CPSMV could be genetically engineered to express foreign antigens on its surface, which would result in effective, non-replicating animal/human vaccines. Such a procedure could be used as a quick, specific and precise method for the production of plant virus-specific antibodies for viral diagnosis.

\section{Acknowledgments}

We thank Dr. Deijanira A. Albuquerque, University of Cincinnati, OH, USA, for competent suggestions.

\section{References}

1. Modelska A, Dietzschold B, Sleysh N, Zhen FK, Steplewski K, Hooper DC, Koprowski H \& Yusibov V (1998). Immunization against rabies with plant-derived antigen. Proceedings of the National Academy of Sciences, USA, 95: 24812485.

2. Fichten J, Beachy RN \& Mein MB (1995). Plant virus expressing hybrid coat protein with added murine epitope elicits autoantibody responses. Vaccine, 13: 10511057.

3. J oelson $\mathrm{T}$, Akerblom $\mathrm{L}$, Oxelfelt $\mathrm{P}$, Strandberg B, Tomenius $\mathrm{K} \&$ Morris TJ (1995). Presentation of a foreign peptide on the surface of tomato bushy stunt virus. J oumal of General Virology, 78: 12131217.

4. Usha R, Rohll JB, Spall VE, Shanks M, Maule AJ, Johnson JE \& Lomonossoff GP (1993). Expression of an animal virus antigenic site on the surface of a plant virus particle. Virology, 197: 366-374.
5. Porta C, Spall VE, Loveland J , J ohnson J E, Barker PJ \& Lomonossoff GP (1994). Development of cowpea mosaic virus as a high yielding system for the presentation of foreign peptides. Virology, 202: 949955.

6. McLain L, Durrani Z, Wisniewski LA, Porta C, Lomonossoff GP \& Dimmock NJ (1996). Stimulation of neutralizing antibodies to human immunodeficiency virus type 1 in three strains of mice immunized with a 22 amino acid peptide of gp41 expressed on the surface of a plant virus. Vaccine, 14: 799-810.

7. Xu F, Jones TD \& Rodgers PB (1996). Potential of chimaeric plant virus particles as novel stable vaccines. Developmental Biology, 87: 201-205.

8. Durrani Z, M Clnemey TL, MCLain L, J ones T, Bellaby T, Brennan FR \& Dimmock NJ (1998). Intranasal immunization with a plant virus expressing a peptide from HIV$1 \mathrm{gp} 41$ stimulates better mucosal and sys- temic HIV-1-specific IgA and IgG than oral immunization. J ournal of Immunological Methods, 1: 93-103.

9. Lomonossoff GP \& J ohnson JE (1991). The synthesis and structure of comovinus capsids. Progress in Biophysics and Molecular Biology, 55: 107-137.

10. Lomonossoff GP \& Hamilton WDO (1997). Cowpea mosaic virus-based vaccines. Plant Biotechnology, 240: 177-189.

11. Brennan FR, Bellaby T, Helliwell SM, J ones TD, Kamstrup S, Dalsgaard K, Flock J I \& Hamilton WD (1999). Chimeric plant virus particles administered nasally induce systemic and mucosal immune responses in mice. J ournal of Virology, 73: 930938.

12. Chen X \& Bruening G (1992). Nucleotide sequence and genetic map of cowpea severe mosaic virus RNA2 and comparisons with RNA2 of other comoviruses. Virology, 187: 682-692.

13. Gaspar LP, J ohnson JE, Silva J L \& Da 
Poian ATJ (1997). Partially folded states of the capsid protein of cowpea severe mosaic virus in the disassembly pathway. J oumal of Molecular Biology, 273: 456466.

14. Partrige JE, Shannon LM, Gumpf DJ \& Colbaugh P (1974). Glycoprotein in the capsid of plant viruses as a possible determinant of seed transmissibility. Nature, 247: 391-392.

15. Murphy FA, Fauquet CM, Bishop DHL, Ghabrial SA, J anvis AW, Martelli GP, Mayo MA \& Summers MD (1995). Virus taxonomy. In: Sixth Report of the International Committee on Taxonomy of $\mathrm{Vi}$ ruses. Archives of Virology (Suppl 10), 341. Springer Verlag, New York.

16. Altmann F \& Lomonossoff GP (2000). Glycosylation of the capsid proteins of cowpea mosaic virus: a reinvestigation shows the absence of sugar residues. J ournal of General Virology, 81: 1111-1114.

17. Florindo MI, Silva ACM, Lima J AA \& Silva Lima M (1997). Produção de anticorpos em camundongos imunizados por via oral com vírus de planta. Fitopatologia Brasileira, 22: 335.

18. Magistris MT (1998). Mucosal adjuvant effect of genetically modified cholera toxin and Escherichia coli heat-labile enterotoxin derivatives. Research in Immunology, 149: 33-35.

19. Strobel S \& Mowat AM (1998). Immune responses to dietary antigens: Oral tolerance. Immunology Today, 19: 173-181.

20. Holmgren J, Bergqvist $M$, Bäckström $C$, Czerkinsky M, Fredriksson EL, J ohansson $M$, Lebens $M$, Lindblad $N$, Mielcarek $C$, Rask C, Rudin A \& Sun J B (1998). New prospects for mucosal immunization: antiinfectious and anti-inflammatory vaccines. Research in Immunology, 149: 29-31.

21. Lima JAA \& Nelson MR (1974). Purifi- cação e identificação sorológica de "cowpea severe mosaic virus" em Vigna sinensis Endl. no Ceará. Ciência Agronômica, 3: 5-8.

22. Bradford MM (1976) A rapid and sensitive method for the quantitation of microgram quantities of protein utilizing the principle of protein-dye binding. Analytical Biochemistry, 72: 248-254.

23. Laemmli UK (1970). Cleavage of structural proteins during the assembly of the head of bacteriophage T4. Nature, 227: 680-685.

24. Towbin J , Staehelin T \& Gordon J (1979). Electrophoretic transfer of proteins from polyacrylamide gels to nitrocellulose sheets: procedures and some applications. Proceedings of the National Academy of Sciences, USA, 76: 4350-4354.

25. Mota I \& Wong D (1969). Homologous and heterologous passive cutaneous anaphylactic activity of mouse anti-sera during the course of immunization. Life Sciences, 8: 813-820.

26. Ovary $Z$ (1958). Passive cutaneous anaphylaxis in the mouse. Journal of Immunology, 81: 355-358.

27. Yousibov V, Modelska A, Steplewski K, Agadjanyan M, Weiner D, Hooper DC \& Koprowski H (1997). Antigen produced in plants by infection with chimeric plant viruses immunized against rabies virus and HIV-1. Proceedings of the National Academy of Sciences, USA, 94: 5784-5788.

28. Kalmar GB \& Eastwell KC (1989). Reaction of coat proteins in different aggregation states with monoclonal antibodies. J ournal of General Virology, 70: 34513457.

29. Aizpunua HJ \& Russel-J ones GJ (1988). Oral vaccination. Identification of classes of proteins that provoke an immune response upon oral feeding. J oumal of Ex- perimental Medicine, 167: 440-451.

30. Boyaka PN, Marinaro M, Vancott J L, Takahashi I, Fujihashi K, Yamamoto M, Van Ginkel FW, J ackson RJ, Kiyono $\mathrm{H} \&$ McGhee JR (1999). Strategies for mucosal vaccine development. American J oumal of Tropical Medicine and Hygiene, 60: 35-45.

31. Bruce MG \& Ferguson A (1986). Oral tolerance to ovalbumin in mice: studies of chemically modified and "biologically filtered" antigen. Immunology, 57: 627-630.

32. Van Der Heijden PJ, Bianchi TJ, Dol M, Pals J W, Stok W \& Bokhout BA (1991). Manipulation of intestinal immune responses against ovalbumin by cholera toxin and its b subunit in mice. Immunology, 72: 89-93.

33. Melo VMM, Xavier-Filho J, Silva-Lima M \& Prouvost-Danon A (1994). Allergenicity and tolerance to proteins from Brazil nut (Bertholletia excelsa h.b.k.). Food and Agricultural Immunology, 6: 185-195.

34. Rabinovitch GA, Riera CM, Landa CA \& Sotomayor CE (1999). Galectins: a key intersection between glycobiology and immunology. Brazilian J oumal of Medical and Biological Research, 32: 383-393.

35. Kowalczyk DW \& Ertl HCJ (1999). Immune response to DNA vaccines. Cell and Molecular Life Sciences, 55: 751-770.

36. Liljeqvist S \& Stähl S (1999). Production of recombinant subunit vaccines: protein immunogens, live delivery systems and nucleic acid vaccines. J oumal of Biotechnology, 73: 1-33.

37. Mowat AM, Thomas MJ, Mackenzie $S \&$ Parrott DMV (1986). Divergent effects of bacterial lipopolysaccharide on immunity to orally administered protein and particulate antigens in mice. Immunology, 58: 677-683. 